\title{
9 Year Compulsory Education Evaluation In Bojonegoro Regency, East Java Province, Indonesia. Year 2015
}

\author{
Dr. Rupiarsieh M.Si \\ Social and Politic Faculty, \\ Bojonegoro University Indonesia
}

\begin{abstract}
Indonesia's 1945 Constitution, Article 31, Sentence 1, stipulates that "each citizen has the right to education." This means that the Indonesian government has the obligation to provide and run a national education system, in order to make intelligent the nation. Then, described in 2003 Law number 20 on National Education System and in 2008 Government Regulation Number 47, on Compulsory Education, that stipulated the Government and Local Government guarantee the execution of compulsory education at the least in basic education without charging any tuition fee; and obligates each region to set up Local Regulation and implement the Basic Compulsory Education Program. The Bojonegroro Regency Regulation Number 4 Year 2012, Article 65, Sentence 1, letter (a) states that: "the Local Government is obligated to set a 12 (twelve) year compulsory education, which comprises of 9 (nine) year basic education and 3 (three) year middle education." It guarantees that each child has access to at the least 9 years of education, and that 9 year basic education expenses is provided for. The evaluation of the 9 year compulsory education in Bojonegero, shows that the average length of education is 6.7 years. It means that the citizen of Bojonegoro having finished the 6 year Elementary School. The aim of 9 year compulsory education hasn't been reached. Using the qualitative descriptive method, show several causal factors. These factors are that school participation is low, there is significant level of illiteracy and school drop outs, and the psychology of rural people who think that to ease the parents' burden, after 6 years of Elementary school the girls are married off and the boys help with earning money. To reach the aim of 9 year compulsory education, there should be a special program to eradicate illiteracy, raising the capacity of Kejar Program A and B, Back to School Movement, and Education Policy that involves both formal and nonformal education.
\end{abstract}

Key Words: Evaluation, Indonesian Education System, Program/Policy, 9 Year Compulsory Education

\section{FOREWORD}

The 1945 Constitution of the Republic of Indonesia, article 31, paragraph 1 states that "every citizen has the right to education". This means that the Indonesian government has the obligation to provide and run a national education system, in order to make intelligent the nation and the increase faith and and good character in the context of educating the nation. Then, described in 2003 Law number 20 on National Education System and in 2008 Government Regulation Number 47, on Compulsory Education, that stipulated the Government and Local Government guarantee the execution of compulsory education at the least in basic education without charging any tuition fee; and obligates each region to set up Local Regulation and implement the Basic Compulsory Education Program.

Bojonegoro Regency Government in order to provide educational services have made Local Goverment Regulation No. 4, 2012, on the Implementation of Education in Bojonegoro. Bylaw is set compulsory in article 65, paragraph 1, letter (a), which reads: "Local Government is obliged to establish compulsory twelve (12) years, including primary education 9 (nine) years and secondary education three (3) years" , This means that local governments guarantee every 
child has a chance to learn at least 9 years, and ensure the availability of the cost of basic education for 9 years. This regulations has been implemented for about 3 years, and the results of initial studies have shown that primary education 9 (nine) years in 2015 has not been reached. These conditions lead researchers to carry out the evaluation of 9-year basic education program or a 9-year compulsory program in Bojonegoro. Given the Bojonegoro district is now a district with rapid growth as a producer of oil and gas, and followed the development of new industry and supporting both the agricultural industry and oil-gas industry, so the level of education is an absolute demand in necessary.

Evaluation of the education program is needed because the process of evaluation of the results will provide some information that can be a consideration in achieving the goals set, seen from the level of achievement and constraints affecting the achievement, as a form of accountability of the implementor. This is consistent with the opinion of Stuffflebeam and shinkfield (1985; 159) in the book Learning Program Evaluation, Prof. Eko Putro Widoyoko (2015) which says: "Evaluation is the process of delinieting, obtaining, and providing descriptive and judgmental information about the worth and meritof some object's goals, design, implementation, and impact in order to guide decision making, serveneeds for accountability, and promote understanding of the involved phenomena". Related with the program compulsory 9 years in Bojonegoro, which has been running in three years, shows that the achievement of program is not run optimally. This evaluation is carried out with the intent and purpose in order to know why the program has not been achieved, what causes it, and the results of this evaluation should able to provide information about things to do, which is input as a policy-making in order to move forward to realize the activities in accordance with the specified program.

\section{INDONESIAN NATIONAL EDUCATION SYSTEM AND 9 YEAR COMPULSORY EDUCATION PROGRAM AT BOJONEGORO REGENCY}

National Education System according to Indonesian Republic Rule No. 20, year 2003, article 1, paragraph (1) is an education based on Pancasila dan Constitution of the Republic of Indonesia Year 1945 is rooted in religious values, national culture of Indonesia and responsive to the changing era. While in the National Education System in accordance with the Rule No. 20 of year 2003 Article 1 paragraph 3 said that is the overall educational components in an integrated manner to achieve national education goals.

National education goals is the development the potential of students to become human beings faith and fear of God Almighty, noble, healthy, knowledgeable, skilled, creative, independent, and become citizens of a democratic and responsible. The level in the national education system is defined by the level of development of learners, objectives to be achieved, and the ability must be develop. The level of national education consists of Elementary Education, Middle Education and High Education. In order to implement the elementary education needs to be made a Government Regulation on Compulsory Education No. 47 Year 2008 concerning Compulsory

9-Year Compulsory Education Program in Bojonegoro is regulated by Regulation No. 4 of year 2012, concerning the organization of education in Bojonegoro Regency. According to this regulation, the compulsory is the minimum educational program to be followed by the citizens of Indonesia, under the responsibility of the Government and Local Government. The purpose of this program has been set in the local rule, chapter II, section 2, Article 3, which reads: The purpose is to provide education: a). Equalization the quality of educational opportunities; b). developing the potential of learners to become a man of faith and devoted to God Almighty, noble, healthy in physic and mental, knowledgeable, skilled, creative, independent and become citizens of a democratic and responsible; c). Improving the quality of learning activities and 
developing the management of education, based on transparant education budget and providing education accountability in overall and community participation.

Compulsory education specifically addressed in chapter XXI, Article 65, which reads as follows: Paragraph (1) Local Government shall: a). establishes compulsory education in twelve (12) years, of basic education in nine (9) years and in three (3) years for secondary education; b). ensure every child gets the opportunity to learn up on secondary education; c). ensuring the availability of basic education costs for the implementation of compulsory twelve (12) years.

From some of the provisions stipulated in the Regulation mentioned above can be interpreted that the compulsitory in 9 (nine) years at Bojonegoro is the basic education level that must be reached, before rising to a secondary education in 12 (twelve) years.

Evaluation in compulsory education is seen as a process of determining the results achieved in several activities planned to promote the goals (Suchman; 1961, in Anderson 1975). Meanwhile, according to an expert evaluation of the program Stufflebeam (1971, in Fernandes 1984) says that the evaluation is a description of the process, searching for and providing useful information for decision makers in determining the decision alternatives.

\section{METHODOLOGY}

In the implementation of this evaluation, the methodology used is qualitative method. This method is used to examine the condition of the object that is natural, (as the opposite of experiment), where the research is as an instrument keys. The data collection techniques is done by triangulation (combined) and using inductive data analysis. (Prof. Dr. Sugiyono, 2005: 1 ), in the opinion of Bogdan and Taylor $(1975 ; 5)$ that the qualitative method is a procedure that produces descriptive data in the form of words written or spoken of people and observed behavior.

The data collected is in the form of documents of implementation the compulsory 9 years in 2015, in the form of Rough Partisipation Index (APK), Real Partisipasion Index (NER), transition index and dropout index, and also interviews to the community / parents, and the child in school-age but don't go to school, and the institutions in the Bojonegoro Regency. All the data is processed and analysed. Responden selected is Head of Office and staff data section, the Office of education and Culture in Bojonegoro Rgency, school-age children are not in school, the community. The researchers randomly determined them in accordance with needs.

In the opinion of Lexy J. Moeloeng, qualitative analysis is research that analytical procedures that do not use statistical analysis procedures or other means of quantification. (Lexy J. Moeloeng, 2006: 6). The analysis used in this study correspond to the type of data required. The method of analysis used as well the method of descriptive and explorative.

\section{EVALUATION OF THE IMPLEMENTATION PROGRAM 9-YEAR COMPULSORY IN BOJONEGORO REGENCY}

\section{Literacy Index}

The literacy index is the proportion of the population aged 15 years and over who can read and write in Latin or others .Literacy index obtained from the percentage of the population over 15 years old, who can read and write by the total population above 15 years. The development of literacy index in Bojonegoro from 2012 to 2015 continued to rise. It showed a success against illiteracy alleviation efforts in Bojonegoro. In 2012 the literacy index in Bojonegoro is 84.60\%. Whereas in 2014 the literacy index increased to $98.60 \%$ or an increase about $14 \%$. And in 
2015, the Department of Education make a breakthrough to improve the literacy index of $100 \%$ for the productive age. As an illustration can be seen in the table below:

Table 4.1

The Developments Literacy Index Year 2012- 2015 in Bojonegoro

\begin{tabular}{|c|c|c|c|c|c|}
\hline Description & Unit & $\mathbf{2 0 1 2}$ & $\mathbf{2 0 1 3}$ & $\mathbf{2 0 1 4}$ & $\mathbf{2 0 1 5}$ \\
\hline Literacy Index & $\%$ & 84.60 & 85,79 & 93,58 & 100 \\
\hline
\end{tabular}

Source: Socio-Economic Macro Data East Java 2012 - 2015

The literacy index of the data, showed that the increase in the literacy index is $100 \%$ focusing on productive age, thus Bojonegoro been completed in eradicating illiteracy in productive age specifically.

\section{The Avarage of Learning Duration}

Every year an increase in learning duration in Bojonegoro regency. Although the average of increase is relatively small. In 2012 the learning duration of Bojonegoro residents aged 15 years and above was 6.4 years, whereas in 2015 the average of learning duration in Bojonegoro was 6.8 years. More details, the average of learning duration from 2012 to 2015 in Bojonegoro can be seen in the chart below:

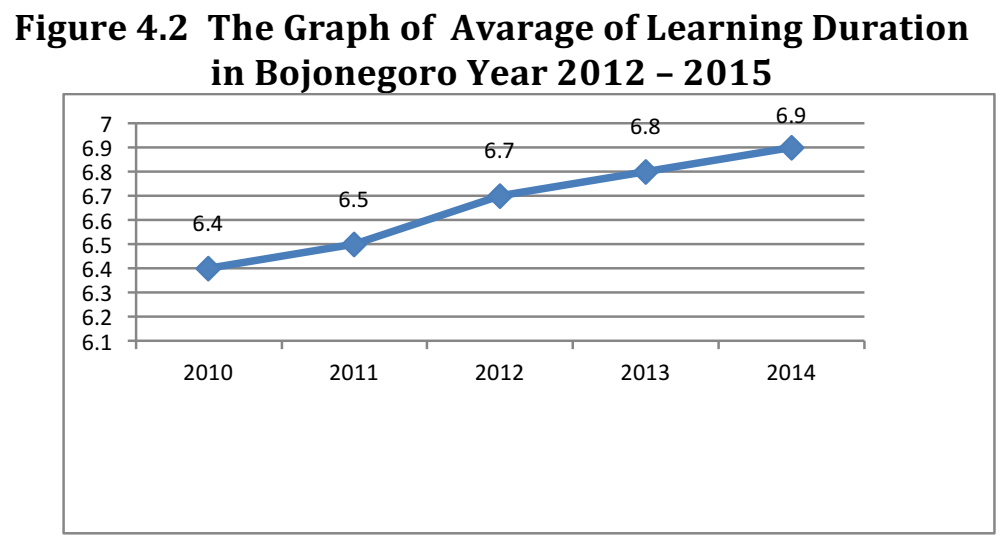

From the average of learning duration in Bojonegoro on the 2015 was 6.8, compared to Medium-Term Education Plan (RPJMD) Year 2014 - 2018, the average of learning duration has not been reached. In order to increase the the average of learning duration, the government must continue the public education program of productive age and older through Learning Packet to emilinate the illteracy, namely Kejar Paket A, B, C.

\section{Rough Participation Index}

The Rough Participation Index is the ratio of the number of students at education level in the elementary / junior / senior high school divided by the population aged 7 to 18 years or the ratio of the number of students, regardless of age, who is studying in a certain educational level of the population of the age group associated with education level . The Rough Participation Index shows the level of participation of the population in general and an educational level. The Rough Participation Index is the simplest indicator to measure the absorption of the school age population at each level of education. The Rough Participation Index developments in Bojonegoro are as follows: 
Tabel. 4.3

The Development of The Rough Participation Index

in Bojonegoro Regency 2012 - 2015

\begin{tabular}{|l|c|c|c|c|}
\hline \multirow{2}{*}{$\begin{array}{c}\text { Description } \\
\text { Of The Rough } \\
\text { Participation } \\
\text { Index }\end{array}$} & $\mathbf{2 0 1 2}$ & $\mathbf{2 0 1 3}$ & $\mathbf{2 0 1 4}$ & $\mathbf{2 0 1 5}$ \\
\cline { 2 - 5 } & 100,98 & 100,99 & 101,01 & 101,01 \\
\hline Elementary School & 99,99 & 100,02 & 100,03 & 104,04 \\
\hline Secondary School & 78,53 & 80,88 & 80,88 & 84,97 \\
\hline Senior High School & &
\end{tabular}

Source : Education Office in Bojonegoro Regency, 2015

From the table above shows that the participation of the population in education at every level of experience has increased, because groups of people who are already literate continuing education through the Kejar Packet

\section{Real Participation Index}

The Real Participation Index is the ratio of the population aged between 7 and 18 years were enrolled at the school level of education as elementary / junior / senior high school divided by the population aged 7 to 18 years. The Real Participation Index shows the percentage of students with age associated with education levels of the population in the same age. The Rough Participation Index and The real Participation Index is also an indicator of the absorption school-age population in every level of education. However, when compared The rough Participation Index, The Real Participation Index is an better indicator to look the absorption at the standard age group population participation in education in accordance with these standards.

Table 4.4.

The Development of The Real Participation Index in Bojonegoro Regency 2012 -2015

\begin{tabular}{|l|c|c|c|c|}
\hline \multirow{2}{*}{$\begin{array}{c}\text { Description of The } \\
\text { Real Participation } \\
\text { Index }\end{array}$} & \multicolumn{4}{|c|}{ Year } \\
\cline { 2 - 5 } & $\mathbf{2 0 1 2}$ & $\mathbf{2 0 1 3}$ & $\mathbf{2 0 1 4}$ & $\mathbf{2 0 1 5}$ \\
\hline Elementary School & 99,11 & 99,45 & 99,71 & 100 \\
\hline Secondary School & 91,66 & 92,55 & 92,55 & 93,44 \\
\hline Senior High School & 71,77 & 75,72 & 75,72 & 80.45 \\
\hline
\end{tabular}

Source : Education Office in Bojonegoro Regency, 2015

As seen on table above, The Real participiation Index in all level are increased, specially in secondary level.

\section{School Participation Index}

One indicator that is often used to measure the performance of educational attainment is the School Participation Index. This indicator shows how much school - age children by a certain educational level are within the scope of education and absorption of formal education to school - age population. The School Participation Index is calculated based on the number of students in basic level per 1,000 population of primary school age 
Table 4.5.

The School Participation Index of Elementary and Secondary School in Bojonegoro Regency $2012-2015$

\begin{tabular}{|c|l|l|r|r|r|r|}
\hline \multirow{2}{*}{ No } & \multirow{2}{*}{ Description } & \multirow{2}{*}{ Unit } & \multicolumn{3}{|c|}{ Existing Year } \\
\cline { 3 - 6 } & & & $\mathbf{2 0 1 2}$ & $\mathbf{2 0 1 3}$ & $\mathbf{2 0 1 4}$ & $\mathbf{2 0 1 5}$ \\
\hline \multirow{2}{*}{1} & \multirow{2}{*}{ Elementary School } & The Rough Participation Index (\%) & 100,98 & 100,99 & 101,01 & 101,01 \\
\cline { 3 - 7 } & & The Real Participation Index(\%) & 99,11 & 99,45 & 92,55 & 92,55 \\
\hline \multirow{2}{*}{2} & \multirow{2}{*}{ Secondary school } & The Rough Participation Index (\%) & 99,99 & 100,02 & 100,03 & 104,04 \\
\cline { 3 - 7 } & & The Real participation Index(\%) & 91,66 & 92,55 & 90,30 & 93,44 \\
\hline \multirow{2}{*}{3} & \multirow{2}{*}{ Senior High School } & The Rough Participation Index (\%) & 78,53 & 80,85 & 80,85 & 80,45 \\
\cline { 3 - 7 } & & The Real participation Index(\%) & 71,77 & 75,72 & 75,72 & 84,97 \\
\hline
\end{tabular}

Source : Education Office in Bojonegoro Regency, 2015

\section{The Availability of School Building and Other Educational Facilities}

Besides The School Participation Index, the indicators of performance in education is the availability of school building and other educational facilities. More specifically the availability of educational facilities in Bojonegoro can be seen in table below:

Table 4.6

The Availability of Educational Facilities

in Bojonegoro Regency 2012 - 2015

\begin{tabular}{|c|l|c|c|c|c|c|}
\hline No & \multicolumn{1}{|c|}{ Description } & Unit & $\mathbf{2 0 1 2}$ & $\mathbf{2 0 1 3}$ & $\mathbf{2 0 1 4}$ & $\mathbf{2 0 1 5}$ \\
\hline \multirow{2}{*}{1} & $\begin{array}{l}\text { Educational facilities in } \\
\text { Elementary School }\end{array}$ & & & & \\
\hline & - School Building & Unit & 1.072 & 1.112 & 1.029 & 1023 \\
\hline & - Class Room & Local & 5.374 & 5.442 & 6.629 & 7217 \\
\hline & - Teacher & Local & 984 & 991 & 1.053 & 9031 \\
\hline & - Library & Local & 833 & 881 & 890 & 923 \\
\hline \multirow{2}{*}{2} & $\begin{array}{l}\text { Educational facilities in } \\
\text { Secondary School }\end{array}$ & & & & & \\
\hline & - School Building & Unit & 216 & 224 & 211 & 218 \\
\hline & - Class Room & Local & 1.692 & 1.782 & 1786 & 1927 \\
\hline & - Teacher & Local & 196 & 209 & 4011 & 4756 \\
\hline & - Library & Local & 111 & 112 & 132 & 139 \\
\hline \multirow{2}{*}{3} & $\begin{array}{l}\text { Educational facilities in Senior } \\
\text { High School }\end{array}$ & & & & & \\
\hline & - School Building & Unit & 134 & 142 & 94 & 149 \\
\hline & - Class Room & Local & 1.125 & 1.221 & 1060 & 1553 \\
\hline & - Teacher & Local & 67 & 74 & 2357 & 3779 \\
\hline & - Library & Local & 133 & 141 & 153 & 169 \\
\hline
\end{tabular}

Source : Education Office in Bojonegoro Regency, 2015

From the data above, shows that the educational facilities at all levels of education have added the number of facilities, ranging from the growing number of teachers, classrooms and libraries. This shows that the quality of education improvement in Bojonegoro goes well.

\section{Number of Graduates and Students Graduation Index}

The increasing number of graduation of students at various levels each school year, is the good condition of all parties, including government and society. But if there is a decrease, it needs to be observed wisely, by looking at the correlation and synergy among students, teachers and the parents. Here presented data on the percentage of the graduation and the number of graduation in Bojonegoro during the period 2012 - 2015 
Table 4.7

The Increasing Number of Graduation, Transition Index and School Capacity in Bojonegoro Regency 2012 - 2015

\begin{tabular}{|c|c|c|c|}
\hline \multirow[b]{2}{*}{ Year } & \multicolumn{3}{|c|}{ The Number of Graduation (\%) } \\
\hline & $\begin{array}{l}\text { Elementary } \\
\text { School }\end{array}$ & $\begin{array}{l}\text { Secondary } \\
\text { School }\end{array}$ & $\begin{array}{c}\text { Senior } \\
\text { High } \\
\text { School }\end{array}$ \\
\hline 2012 & 100.00 & 94,21 & 98.69 \\
\hline 2013 & 99,87 & 99,70 & 99,79 \\
\hline 2014 & 100,00 & 99,80 & 99,81 \\
\hline 2015 & 100,00 & 100,00 & 100,00 \\
\hline \multirow[b]{2}{*}{ Year } & \multicolumn{3}{|c|}{ Transition Index (\%) } \\
\hline & $\begin{array}{c}\text { Elementary } \\
\text { School }\end{array}$ & \multicolumn{2}{|c|}{$\begin{array}{c}\text { Secondary and } \\
\text { Senior High School }\end{array}$} \\
\hline 2012 & 99,14 & \multicolumn{2}{|c|}{94,94} \\
\hline 2013 & 99,68 & \multicolumn{2}{|c|}{96,03} \\
\hline 2014 & 99,72 & \multicolumn{2}{|c|}{97,33} \\
\hline 2015 & 99,83 & \multicolumn{2}{|c|}{98,02} \\
\hline \multirow[b]{2}{*}{ Year } & \multicolumn{3}{|c|}{ School Capacity } \\
\hline & $\begin{array}{l}\text { Elementary } \\
\text { School }\end{array}$ & $\begin{array}{l}\text { Secondary } \\
\text { School }\end{array}$ & $\begin{array}{c}\text { Senior } \\
\text { High } \\
\text { School }\end{array}$ \\
\hline 2012 & 112 & 264 & 302 \\
\hline 2013 & 114 & 263 & 306 \\
\hline 2014 & 114 & 263 & 306 \\
\hline 2015 & 106 & 245 & 298 \\
\hline
\end{tabular}

Source : Education Office in Bojonegoro Regency, 2015

Based on these data, the percentage of elementary graduation in Bojonegoro years 2012 - 2015 was $100 \%$, which means that students fully pass on elementary education (SD / MI), except in 2013 amounted to $99.87 \%$. In 2015 for secondary (SMP/MTs) increased graduation to 100\%, as well as to senior high school (SMA/MA) graduation in Bojonegoro reaches 100\%. This condition is a proud achievement for Bojonegoro, for all levels of graduation reached $100 \%$ pass. This achievement is also followed by the increase transition index rise by $0.11 \%$ from the previous year's level of SD / MI and SMP / MTs and 0.69\% for senior high / MA. But to school capacity in 2015 has decreased for all levels of education, compared to 2014

\section{The Children do not Attend the School in 2015}

The children in school age who do not attend the school is also one indicator that is often used to measure the performance of educational attainment. This indicator shows how much school-age children do not attend school, according its level. The greater the numbers in education, it indicates the dropout index. These conditions affect the average long term learning. 
Table 4.8

The Children Do Not Attend The School in Bojonegoro

\begin{tabular}{|c|c|c|c|c|}
\hline \multirow[b]{2}{*}{ No } & \multirow[b]{2}{*}{ Sub-Regency } & \multicolumn{3}{|c|}{ Level of Education } \\
\hline & & $\begin{array}{c}\text { Elementary } \\
\text { School (SD/MI) } \\
7-12 \text { years old }\end{array}$ & $\begin{array}{l}\text { Secondary School } \\
\text { (SMP/MTs) } \\
13-15 \text { years old }\end{array}$ & $\begin{array}{c}\text { Senioor High School } \\
\text { (SMA/SMK/MA) } \\
16-18 \\
\text { yaers old }\end{array}$ \\
\hline 1 & Balen & 21 & 91 & 108 \\
\hline 2 & Baureno & 19 & 8 & 9 \\
\hline 3 & Bojonegoro & 10 & 12 & 33 \\
\hline 4 & Bubulan & 1 & 3 & 3 \\
\hline 5 & Dander & 29 & 225 & 283 \\
\hline 6 & Gayam & 1 & 2 & 2 \\
\hline 7 & Gondang & 3 & 1 & 3 \\
\hline 8 & Kalitidu & 11 & 42 & 20 \\
\hline 9 & Kanor & 5 & 11 & 17 \\
\hline 10 & Kapas & 9 & 20 & 15 \\
\hline 11 & Kasiman & - & 3 & 12 \\
\hline 12 & Kedewan & 3 & 17 & 56 \\
\hline 13 & Kedungadem & 36 & 64 & 36 \\
\hline 14 & Kepohbaru & 12 & 17 & 47 \\
\hline 15 & Malo & 140 & 30 & 11 \\
\hline 16 & Margomulyo & 6 & 15 & 11 \\
\hline 17 & Ngambon & 11 & 15 & 6 \\
\hline 18 & Ngasem & 133 & 81 & 353 \\
\hline 19 & Ngraho & 5 & 38 & 439 \\
\hline 20 & Padangan & 24 & 26 & 30 \\
\hline 21 & Purwosari & 15 & 11 & 14 \\
\hline 22 & Sekar & 9 & 67 & 113 \\
\hline 23 & Sugihwaras & 3 & 17 & 4 \\
\hline 24 & Sukosewu & 7 & 49 & 242 \\
\hline 25 & Sumberrejo & 11 & 15 & 81 \\
\hline 26 & Tambakrejo & 57 & 91 & 134 \\
\hline 27 & Temayang & 15 & 56 & 127 \\
\hline 28 & Trucuk & - & 10 & 4 \\
\hline & Total & 596 & 1037 & 2214 \\
\hline
\end{tabular}

Source : Education Office in Bojonegoro Regency, 2015

The table above shows that the higher the level of education, number of children do not getting the school is high. It can be calculated that in 2015, 1633 children in elemen tary school age do not attend the school, and it was very influential on the implementation of compulsory education. Given the number of primary school age children 9 (nine) years, many are not go school. This means that the 9 (nine) years compulsory, has not run optimally in Bojonegoro.

\section{Psychological Factors of Children do not Attend School}

In addition to factors of technical, non-technical factors also greatly affect the child does not attend school. These factors are economic factors and social-psycoligacl factors. Especially in rural communities that consider that after six years primary school to reduce the burden on parents, the girls is married, and the boys go to work to help find some money. From the interviews with school dropouts and parents, their opinion is as follows:

1) "I do not go to school, because I help my mother to sell at markets, my father at home".

2) "I do not want to continue my school to junior high school, because my parents can not pay for school, let my sister go to school, I want to find some work to help my parents". 
3 ) "In village children do not need to be high education, elementary school is enough, let them to be married, to lighten the burden of the parents"

4) "I do not want to go to school, because my father said it's better to work to help my parents, which is I already able to read and write".

From the intervieuw, we know that a program related to public policy will work well and effectively, takes the form of socialization of the good sense and the right to the public about the importance of this program in the run, in order to get full support from all elements of society. The factors that influence the success of the nine year compulsory program, in the terms of the socio-cultural is as follows:

\section{Education Level of Parents}

Education of parents will greatly affect the pattern for educating children. Because it will conect with the perception of parents towards the school itself. In some communities the skills of reading and writing, as well as primary school graduates are generally enough to understand simple problem of living. Most parents only got lower education as well elementary graduation. In this conditions, can happen several possibilities, such as not sending their children to school or dismisses her son prematurely.

\section{Society Tradition Factor}

Traditions and customs of the community often impede the participation of children to school. From some areas there is still a tradition of children to participate traveling away with their parents, such as visiting their family. Parents do not feel guilty even though taking his son to leave the school in the long term.Another tradition is still many people in society who believe educating girls is less profitable, so that parents are reluctant to send girls to the school. Because in the end, the girls will be a housewife, who only take care of the house working that are considered not require high school. Another tradition in the community is about to marry off girls at a young age. Because if they have a girl child is old enough, but not to get married in early, it becomes a burden and disgrace in the family.

\section{Economic Factor}

Poverty affects the level of education. Many rural residents are below the poverty line. The poverty index determine the drop out index of school. The parents cannot send their children to school, because they do not have enough money for the school fee. Their children must help their parents to work for getting better life.

\section{Nine Year Compulsory Education Evaluation in Bojonegoro Regency}

From all the data that has been presented above when evaluated in terms of the implementation of the nine (9) year compulsory education program in Bojonegoro, shows the following:

1. From the adult literacy index, indicate that Bojonegoro already carry out the completion of illiteracy in 2015 for productive age, while the unproductive age are still many who are illiterate, and the literacy index is not accompanied by the intensity of education through the Packet Kejar Program.

2. From the indicators the average of learning duration in Bojonegoro Regency, showed 6.8 years. This is due to people who have completed literacy program is not followed by Kejar Packet as the advanced form of education. And unproductive are still many who are illiterate.

3. From the Rough Participation Index, all levels of education has increased. It is as a result of an increase in the literacy rate of productive age, and this condition when associated 
with Medium-Term Education Plan (RPJMD) Bojonegoro years 2014 - 2018, the Rough Participation Index is reached.

4. The Real Participation Index in 2015 also increased, but not in accordance with the target in Medium-Term Education Plan (RPJMD) Bojonegoro, so these index affect the implementation of the 9-year compulsory education program in Bojonegoro.

5. The Transition Index and graduation index indicates the difference between the graduation rate and the transition rate. It can be concluded that there is no continuing education to secondary school or senior high school. It also means not achieving the 9year compulsory education in Bojonegoro.

6. From the number of school-age children who do not attend the school is in high level. It affects the The Rough Participation index and Real Participation Index and the average of learning duration. Therefore, it is required of Bojonegoro government policy to enforce compulsory education, to get them immediately return to school.

7. From the social psychological factors as economic factors, helping their parents, and get married to reduce the burden on parents. All the factors affects the number of children who do not attend the school. Hopefully the government make a regulation to ban school age children to get working, or free schooling and socialization the terms of marriage.

From the results of the evaluation of each indicator of education \ performance in the framework of compulsory education as a trust legislation Bojonegoro number 4, year 2012, concerning the provision of education in the Bojonegoro Regency, indicating that the compulsory education program in Bojonegoro has not been reached, so that the program is run by purpose, the government is expected to make relevant policies, so that the 9-year compulsory education program can be run in Bojonegoro

\section{Conclusion}

\section{CONCLUSION AND RECOMENDATION}

From the description of the background and purpose of the evaluation, as well as the methods used in the evaluation of the 9 (nine) years compulsory program, as stipulated in Bojonegoro Regulation No. 4 of year 2012, concerning the provision of education in Bojonegoro, we can conclude as the following:

1. The literacy index is very influential on compulsory education 9 year in Bojonegoro, because the increase in the literacy rate is onlyin the productive age, while the unproductive age remain illiterate.

2. The average of learning duration of schooling is still low, at 6.8 years, which still far from the target. The literacy people is not directed to pursue education in Kejar Packet (a program to eliminate the illiteracy). The unproductive age people are still illiterate.

3. The Rough Participation Index and The Raeal Participation Index have not been targeted which is set, so that this contributes to the 9 year compulsory education

4. There is the high difference between graduation rates and transition index, which show that children do not continue to pursue higher education, especially from elementary level (SD / MI) to secondary level (SLP / MTs)

5. There are large number of school-age children do not attend the school. It need to get attention of the government to make "back to school program" and implemented for free

6. The social psychological factors that cause parents allow their children out of school, such as economic constraints, working to help the economy of parents and married for girls to reduce the economic burden of their parents. In this case the children do not continue schools will affect the the learning duration, the Rough Participation Index and The real Participation Index. It severely hamper performance to achieve 9 - year 
compulsory education program. With these conditions expected the Local Government of Bojonegoro provide socialization on the dangers of early marriage, and give strict punishment to parents employing children of school age.

\section{Recomendation}

The result of evaluation of the Bojonegoro Regulation no. 4 year 2012 on the implementation of Education in Bojonegoro; recommend a few things that are expected to be done by the government, as follow:

1. Increased the capacity the Kejar Packet A and B

2. The Goverment set a new program in education, namely: "Back to School Program"

3. Make the regulation in formal education and nonformal education to succeed the 9 year compulsory education program, no exception to the right of every citizen to education equally.

4. Socialize the mature age to get marriage to the parents and the importance of family planning for building the healthy family.

5. Give strict punishment to parents employing children of school age.

6. Compulsory program requires a commitment of both society and government. The cooperation between the private sector and the government in the provision of scholarships, will be an opportunity to go to school.

7. The learning duration should not be the substance, but the competency to be achieved learners to face today and tomorrow, in order to educate the nation.

8. Involving community organizations to provide information and new paradigm to parents about the importance of formal schooling for their children in digital era.

\section{BIBLOGRAPHY}

Badan Pusat Statistik, Bojonegoro Dalam Angka, 2015, Kabupaten Bojonegoro

Bogdon dan Taylor, Dalam Metode Penelitian Kualitatif Lexy J. Moeloeng, Remaja Rosda Karya, Bandung, 1990.

Eko Putro Widoyoko, Prof. Dr MPd, Dalam Evaluasi Program Pembelajaran, Penerbit Pustaka Pelajar, Yogyakarta, 2015

Sugiyono, Prof. Dr, Memahami Penelitian Kualitatif, CV. Alfabeta, Bandung, 2005.

Welbum, $1978: 4$

Suharsini Arikunto, Prof. dr dan Cepi Safrudin Abdul Jabar, M.Pd, Dalam Evaluasi Program Pendidikan, Penerbit Bumi Aksara, Jakarta, 2008

\section{DOCUMENT}

Undang-Undang Dasar 1945 Teramandemen

Peraturan Pemerintah Republik Indonesia No.47, Tahun 2008, Tentang Wajib Belajar

Peraturan daerah kabupaten Bojonegoro, No. 4, tahun 2012, Tentang Penyelenggaraan Pendidikan di Kabupaten Bojonegoro.

RPJMD Diknas kabupaten Bojonegoro, tahun 2014 - 2018. 